\title{
Serum Sodium Measurement
}

National Cancer Institute

\section{Source}

National Cancer Institute. Serum Sodium Measurement. NCI Thesaurus. Code C61029.

A quantitative measurement of the amount of sodium present in a sample of serum. 